\title{
Response of african marigold to NPK, biofertilizers and spacings
}

\author{
Manoj Kumar Rolaniya*, S. K. Khandelwal, A. Choudhary and Priynka Kumari Jat \\ Department of Horticulture, S. K. N. Agriculture University, Jobner, Jaipur-303329 (Rajasthan), INDIA \\ *Corresponding author. E-mail: manojetawa91@gmail.com
}

Received: July 16, 2016; Revised received: November 26, 2016; Accepted: February 23, 2017

\begin{abstract}
A field experiment on African marigold (TagetserectaL.) was conducted during winter season of 2014-15 to study the effect of NPK, biofertilizers and plant spacings on growth and yield of African marigold (Tageteserecta Linn). The treatment combinations $\mathrm{F}_{6} 100 \%$ RDF of NPK + Azotobacter + PSB recorded the maximum longevity of intact flower (27.93), average diameter of flower $(7.37 \mathrm{~cm})$, average weight of flower $(8.96 \mathrm{~g})$ number of flowers per plant (56.54), yield of flowers per plant $(515.62 \mathrm{~g})$, per plot $(11.93 \mathrm{~kg})$ and highest flower yield ha $(184.13 \mathrm{q})$. The spacing $D_{3}(60 \times 60 \mathrm{~cm})$ registered significant $(5 \%)$ maximum longevity of intact flower, larger size flower $(7.80 \mathrm{~cm})$, average weight of flower $(9.14 \mathrm{~g})$ and highest flower yield per plant $(456.22 \mathrm{~g})$. Highest flower yield per plot (10.19 $\mathrm{kg}$ ), number of flower per plant (52.22) and per hectare flower yield $(157.29 \mathrm{q} / \mathrm{ha})$ with $60 \times 45 \mathrm{~cm}$. These results are conclusive that application of $100 \%$ RDF of NPK + Azotobacter+ PSB and plant spacing $(60 \times 45 \mathrm{~cm})$ may positively increase the growth and flowers yield parameters of marigold.
\end{abstract}

Keywords: African marigold, Bio fertilizers, NPK, Plant spacing

\section{INTRODUCTION}

African marigold (TageteserectaL.) belongs to family Asteraceae and is a very popular commercial flower crop as loose flower in India because of its wide adaptability to various soils, climatic conditions and easy cultivation. Marigold is having ornamental, medicinal and industrial uses, and it has additional use in controlling the soil nematodes. All varieties of marigold are resistant against root knot nematode, Meloidogyne incognita and could be used to control M. incognita in highly infested areas (Warden and Windrich,1974; and Natarajan et al., 2006). It is an established fact that nutrition plays an important role in the improvement of growth and yield in marigold. Nutrients are directly affected by the vegetative growth and yield of crop. Adequate supply of nutrients especially N, P and K are often considered important for realizing the maximum yield of any crop.

Nitrogen is the chief constituent of several important elements like protein, nucleic acid and amino acids accruing in the plants. It is unequivocal that nitrogen is an essential element required by all the plants, however, it is found to be deficient in most of Indian soil (Arakeri et al., 1956) especially in soils of Rajasthan. Phosphorus is also a major nutrient required by the crops. About 98 per cent soil of cultivated area in India needs phosphorus fertilization for good harvest (Luthra et al., 1983 and Ahirwar et al. 2012). Application of phosphorus not only increases the crop yield but also improves the quality.

Potassium is not a constituent of any plant tissue or compounds but it is involved in the synthesis of amino acids. It imparts vigor and disease resistance to plants. Bio-fertilizers play an important role in increasing availability of nutrients and productivity in sustainable manner. Azotobacter is a free-living bacterium which may add $25-30 \mathrm{~kg}$ nitrogen/ha/year in a field of nonlegume crop under favorable condition and also secretes some growth promoting substances. Therefore, inoculation of seedlings with PSB culture increases nodulation, crop growth, nitrogenase activity, nutrient uptake and crop yield.

The spacing played an important role for manipulating plant growth, flowering behavior and seed yield. Therefore, inter row and intra row spacing and balanced supply of nutrients are important for obtaining higher yield of good quality seeds (Sunitha et al., 2007).

The present experiment was initiated with an objective to study the effect of different fertility levels and different spacing on flowering and yield of African marigold cv. Pusa Narangi Gainda to work out optimum dose of fertility levels and spacing.

\section{MATERIALS AND METHODS}

The field experiment was carried out at Department of Horticulture, S.K.N. College of Agriculture, Jobner during rabi season 2014-15. The fertilizer recommend of $100 \%$ RDF of (NPK- 120:80:60 kg / ha) and seedling treated with biofertilizer (azotobacterand PSB). The treatments consist seven combination of fertilizer i.e. $\mathrm{F}_{0}$ (Control), $\mathrm{F}_{1}(50 \% \mathrm{RDF}$ of $\mathrm{NPK}), \mathrm{F}_{2}(50 \% \mathrm{RDF}$ of NPK + Azotobacter + PSB $), \mathrm{F}_{3}(75 \%$ RDF of 
$\mathrm{NPK}), \mathrm{F}_{4}(75 \% \mathrm{RDF}$ of NPK + Azotobacter $+\mathrm{PSB}), \mathrm{F}_{5}$ (100\% RDF of NPK), $\mathrm{F}_{6}(100 \%$ RDF of NPK + Azotobacter+ PSB), and three combination of plant spacings, $\mathrm{D}_{1}(45 \times 45 \mathrm{~cm}), \mathrm{D}_{2}(60 \times 45 \mathrm{~cm}), \mathrm{D}_{3}(60 \times 60$ $\mathrm{cm})$, making 21 treatment combinations of which were replicated three randomized block design with factorial approach. One month old seedlings were transplanted at different spacing in factorial RBD design.

The observations on longevity of intact flower: Number of days from flower opening to loss the market value of flower for five flowers on each tagged plants were counted and averages were computed. The diameter of fully opened flower was recorded in centimeters with the help of veneer calipers and averages were computed.

Weight of flower: Mean weight of five flowers selected from tagged plants was taken just after harvest and averages were calculated, number of flowers per plant total number of flowers was counted at each picking on the five randomly selected and tagged plants in each plot. These numbers of flowers of each picking was added and averages were computed.

Table1. Effect of NPK, biofertilizers and plant spacing on flowering parameters on number of flowers per plant,average weight of flower, average diameter of flower,longevity of intact flower,yield of flowers per plot and yield of flowers per ha.

\begin{tabular}{|c|c|c|c|c|c|c|c|}
\hline Treatment & $\begin{array}{c}\text { Number of } \\
\text { flowers } \\
\text { per plant }\end{array}$ & $\begin{array}{c}\text { Average } \\
\text { weight of } \\
\text { flower (g) }\end{array}$ & $\begin{array}{l}\text { Average diam- } \\
\text { eter of flower } \\
(\mathrm{cm})\end{array}$ & $\begin{array}{c}\text { Longevity of } \\
\text { intact flower } \\
\text { (days) }\end{array}$ & $\begin{array}{c}\text { Yield of } \\
\text { flowers per } \\
\text { plant (g) }\end{array}$ & $\begin{array}{c}\text { Yield of } \\
\text { flowers per } \\
\text { plot (kg) }\end{array}$ & $\begin{array}{c}\text { Yield of } \\
\text { flowers per } \\
\text { ha (q) }\end{array}$ \\
\hline \multicolumn{8}{|l|}{ Fertility Level } \\
\hline $\mathrm{F}_{0}$ & 33.28 & 5.34 & 5.17 & 21.68 & 180.71 & 4.18 & 64.53 \\
\hline $\mathrm{F}_{1}$ & 39.22 & 6.20 & 6.12 & 23.32 & 247.35 & 5.72 & 88.33 \\
\hline $\mathrm{F}_{2}$ & 44.84 & 6.92 & 6.55 & 24.17 & 315.68 & 7.31 & 112.73 \\
\hline $\mathrm{F}_{3}$ & 49.00 & 7.84 & 6.83 & 25.29 & 390.90 & 9.05 & 139.59 \\
\hline $\mathrm{F}_{4}$ & 52.45 & 8.31 & 7.13 & 26.57 & 443.55 & 10.26 & 158.40 \\
\hline $\mathrm{F}_{5}$ & 54.63 & 8.69 & 7.26 & 27.35 & 483.19 & 11.18 & 172.55 \\
\hline $\mathrm{F}_{6}$ & 56.54 & 8.96 & 7.37 & 27.93 & 515.62 & 11.93 & 184.13 \\
\hline SEm+ & 1.22 & 0.14 & 0.14 & 0.43 & 13.64 & 0.21 & 3.22 \\
\hline $\mathrm{CD}$ at $5 \%$ & 3.49 & 0.40 & 0.41 & 1.22 & 39.00 & 0.59 & 9.21 \\
\hline \multicolumn{8}{|l|}{ Spacing } \\
\hline $\mathrm{D}_{1}(45 \times 45 \mathrm{~cm})$ & 40.64 & 5.35 & 5.15 & 22.15 & 223.54 & 7.15 & 110.39 \\
\hline $\mathrm{D}_{2}(60 \mathrm{x} 45 \mathrm{~cm})$ & 52.22 & 7.91 & 6.95 & 25.56 & 424.67 & 10.19 & 157.29 \\
\hline $\mathrm{D}_{3}(60 \times 60 \mathrm{~cm})$ & 48.55 & 9.14 & 7.80 & 27.85 & 456.22 & 8.21 & 126.73 \\
\hline $\mathrm{SEm}+$ & 0.80 & 0.09 & 0.09 & 0.28 & 8.93 & 0.13 & 2.11 \\
\hline $\mathrm{CD}$ at $5 \%$ & 2.28 & 0.26 & 0.27 & 0.80 & 25.53 & 0.38 & 6.03 \\
\hline
\end{tabular}

Table 2. Interactive effect of NPK, biofertilizers and plant spacing on average weight of flower,yield of flowers per plant, yield of flowers per plot and yield of flowers per ha.

\begin{tabular}{|c|c|c|c|c|}
\hline Treatment & $\begin{array}{c}\text { Average weight of } \\
\text { flower (g) }\end{array}$ & $\begin{array}{c}\text { Yield of flowers per } \\
\text { plant (g) }\end{array}$ & $\begin{array}{c}\text { Yield of flowers per } \\
\text { plot (kg) }\end{array}$ & $\begin{array}{c}\text { Yield of flowers per ha } \\
(q)\end{array}$ \\
\hline $\mathrm{F}_{0} \mathrm{D}_{1}$ & 3.82 & 109.73 & 3.51 & 54.19 \\
\hline $\mathrm{F}_{0} \mathrm{D}_{2}$ & 5.65 & 208.46 & 5.00 & 77.21 \\
\hline $\mathrm{F}_{0} \mathrm{D}_{3}$ & 6.53 & 223.94 & 4.03 & 62.21 \\
\hline $\mathrm{F}_{1} \mathrm{D}_{1}$ & 4.44 & 150.19 & 4.81 & 74.17 \\
\hline $\mathrm{F}_{1} \mathrm{D}_{2}$ & 6.57 & 285.34 & 6.85 & 105.68 \\
\hline $\mathrm{F}_{1} \mathrm{D}_{3}$ & 7.59 & 306.53 & 5.52 & 85.15 \\
\hline $\mathrm{F}_{2} \mathrm{D}_{1}$ & 4.96 & 191.68 & 6.13 & 94.66 \\
\hline $\mathrm{F}_{2} \mathrm{D}_{2}$ & 7.33 & 364.15 & 8.74 & 134.87 \\
\hline $\mathrm{F}_{2} \mathrm{D}_{3}$ & 8.47 & 391.20 & 7.04 & 108.67 \\
\hline $\mathrm{F}_{3} \mathrm{D}_{1}$ & 5.62 & 237.35 & 7.60 & 117.21 \\
\hline $\mathrm{F}_{3} \mathrm{D}_{2}$ & 8.31 & 450.92 & 10.82 & 167.01 \\
\hline $\mathrm{F}_{3} \mathrm{D}_{3}$ & 9.60 & 484.42 & 8.72 & 134.56 \\
\hline $\mathrm{F}_{4} \mathrm{D}_{1}$ & 5.96 & 269.32 & 8.62 & 133.00 \\
\hline $\mathrm{F}_{4} \mathrm{D}_{2}$ & 8.81 & 511.16 & 12.28 & 189.50 \\
\hline $\mathrm{F}_{4} \mathrm{D}_{3}$ & 10.18 & 549.67 & 9.89 & 152.69 \\
\hline $\mathrm{F}_{5} \mathrm{D}_{1}$ & 6.23 & 293.39 & 9.39 & 144.89 \\
\hline $\mathrm{F}_{5} \mathrm{D}_{2}$ & 9.21 & 557.38 & 13.38 & 206.44 \\
\hline $\mathrm{F}_{5} \mathrm{D}_{3}$ & 10.64 & 598.79 & 10.78 & 166.33 \\
\hline $\mathrm{F}_{6} \mathrm{D}_{1}$ & 6.42 & 313.08 & 10.02 & 154.61 \\
\hline $\mathrm{F}_{6} \mathrm{D}_{2}$ & 9.50 & 594.79 & 14.27 & 220.29 \\
\hline $\mathrm{F}_{6} \mathrm{D}_{3}$ & 10.97 & 638.98 & 11.50 & 177.49 \\
\hline SEm+ & 0.24 & 23.63 & 0.36 & 5.58 \\
\hline $\mathrm{CD}(\mathrm{p}=0.05)$ & 0.70 & 67.55 & 1.02 & 15.95 \\
\hline
\end{tabular}


The yield of flowers per plant: Flowers plucked from each of the tagged plant were weighed separately with help of digital balance at each harvesting till the final harvesting of flowers. All the noted values were summed up at last and then the average flower yield per plant in grams was calculated per plot. Fresh flowers were harvested periodically and the weight was recorded with the help of single pan balance in kilogram. The total of each plot was expressed as flower yield per plot in kilogram. The flower yield per plot was converted on hectare basis to reflect the yield of flowers per hectare in quintals.

\section{RESULTS AND DISCUSSION}

The growth characters differed significantly for the various NPK, biofertilizers (Azotobacter + PSB) and plant spacing on growth (Table 1). The maximum longevity of intact flower (27.93), average diameter of flower $(7.37 \mathrm{~cm})$, average weight of flower $(8.96 \mathrm{~g})$ number of flowers per plant (56.54), yield of flowers per plant $(515.62 \mathrm{~g})$, per plot $(11.93 \mathrm{~kg})$ and highest flower yield ha (184.13 q) were recorded with $100 \%$ RDF of NPK + Azotobacter + PSB . While the minimum longevity of intact flower (21.68), lowest diameter of flower $(5.17 \mathrm{~cm})$, lowest weight of flower $(5.34$ g), minimum number of flowers per plant (33.28), lowest yield of flowers per plant $(180.71 \mathrm{~g})$, minimum per plot $(4.18 \mathrm{~kg})$ and minimum yield per hectare (64.53) were recorded with control. The spacing (60× $60 \mathrm{~cm}$ ) registered significantly $5 \%$ maximum longevity of intact flower, larger size flower $(7.80 \mathrm{~cm})$, heaviest flower $(9.14 \mathrm{~g})$, highest flower yield per plant $(456.22 \mathrm{~g})$ and highest flower yield per plot $(10.19 \mathrm{~kg})$, number of flower per plant (52.22) and highest flower yield $(157.29 \mathrm{q} / \mathrm{ha})$ with $60 \times 45 \mathrm{~cm}$. Whereas minimum longevity of intact flower (22.15), small flower $(5.15 \mathrm{~cm})$, lowest flower weight $(5.35 \mathrm{~g})$, minimum flower yield per plant (40.64 g) and lowest flower yield per plot $(7.15 \mathrm{~kg})$, minimum number of flower per plant (40.64) and lowest flower yield (110.39 q/ha) were recorded control. Results (Table 2) reveal that interaction of fertility levels \& plant spacing had the maximum average weight of flower (10.97 gm) and yield of flowers per plant $(638.98 \mathrm{gm})$ were recorded with $100 \%$ RDF of NPK + Azotobacter + PSB along with $60 \times 45 \mathrm{~cm}$ spacing and yield of flowers per plot $(14.27 \mathrm{~kg})$, per hectare $(220.29 \mathrm{q})$ were recorded with $\mathrm{F}_{6} \mathrm{D}_{2}$ while, yield of flowers per plot $(3.51 \mathrm{~kg})$ and per hectare $(54.19 \mathrm{~kg})$ were recorded with control $\left(\mathrm{F}_{0} \mathrm{D}_{1}\right)$.

The positive effect of nutrients supplied through NPK fertilizers and inoculation of biofertilizers on flowering behaviour might be ascribed the fact that nitrogen accelerate the development of reproductive phases, increased the protein synthesis thus promoting earlier floral primordial development in marigold (Acharya and Dashora, 2004). Supply of nitrogen in the life of a plant is considered to be important in promoting rapid growth thereby increasing net photosynthesis on one hand and greater mobilization of photosynthesis towards sink, on the other hand, it might have increased the values of yield. It plays an important role in plant metabolism by virtue of being an essential constitute of diverse types of metabolically active compounds of cell like amino acids, protein, nucleic acid, enzymes, co-enzymes and alkaloids (Baboo and Singh, 2003).

Phosphorus is a component of many energy rich compounds in plants and also increases entire root growth and helps in uptake of other nutrients resulting in increase in yield (Singh et al., 2015). Potassium increases the rate of photosynthesis and mobilization of sucrose to the shoots which have positive influence in flower initiation (Stockman et al., 1983). NPK $(120: 80: 60 \mathrm{~kg} / \mathrm{ha})$ helps in the protein synthesis and increases resistance against stress which might have improved growth and development of the plant which ultimately increased maximum longevity of intact flower, larger size flower, average weight of flower and highest flower yield per plant highest flower yield per plot, number of flower per plant and per hectare flower yield the. These similar result was seen in the findings of Sharma et al. (2006) in chrysanthemum. Azotobacter and PSB are reported to produce growth promoting substances and other acids like acetic, formic, glycolic, fumaric and succinic, which were positively correlated with growth and flowering and helps in branching and development of side buds thus increased early flowering (Wange and Patil, 1994). Improvement in diameter, weight of flower and number of flowers per plant, yield per plant, yield per plot and yield per hectare due to application of Azotobacter and PSB ascribed due to better nitrogen fixation under Azotobacter and greater solubilization of insoluble phosphorus and some other factors such as release of growth promoting substances and proliferation of beneficial organisms in rhizosphere (Barea and Brown, 1974). The results are in consonance with Mittal et al. (2010) in marigold. It might be due to more leaf area, ultimately increased photosynthetic activity and accumulation of carbohydrates in the flowers (Deshmane et al., 2012). The increase in size and weight of flowers at wider spacing could be attributed to availability of greater space and light for photosynthesis with higher availability and uptake of nutrients by the plants which could have enhanced cell division, cell elongation as well as protein synthesis and greater accumulation of dry matter in larger sized sink (flower). Different plant spacing markedly influenced the number of flowers per plant Marigold planted at spacing recorded highest number of flower per plant. This may be attributed to less competition among the plants for nutrients (Pal and Pandey (2007) in marigold (Kour et al. (2009) in chrysanthemum, Khalaj et al. (2012) in tuberose.

The highest flower yield per plant, per plot and per hectare might appear due to higher number of flowers 
produced per plant along with heaviest and larger size flowers because of less competition among the plants (Dorajeerao and Mokashi (2013), Kour (2009) in garland chrysanthemum, Yadav et al. (2004) in African marigold, Sunitha et al. (2007) in marigold and Lakshmi et al. (2014) in african marigold.

Interaction effect: The interaction among the various combinations of NPK applied alone or with biofertilizers (Azotobacter + PSB) along with various plants spacing had a significant effect on average weight of flower, flower yield per plant, per plot and per hectare (Table 2). Application of $100 \%$ RDF of NPK + Azotobacter + PSB culture along with spacing of $60 \times 60$ $\mathrm{cm}\left(\mathrm{F}_{6} \mathrm{D}_{3}\right)$ exhibited heaviest flower $(10.97 \mathrm{~g})$ followed by $100 \%$ RDF of NPK along with spacing of $60 \times 60 \mathrm{~cm}\left(\mathrm{~F}_{5} \mathrm{D}_{3}\right)$, where flower weight was $10.64 \mathrm{~g}$. Similarly, maximum flower yield per plant (638.98 g) was registered with $100 \%$ RDF of NPK + Azotobacter + PSB culture + spacing of $60 \times 60 \mathrm{~cm}\left(\mathrm{~F}_{6} \mathrm{D}_{3}\right)$ followed by $100 \%$ RDF of NPK + spacing of $60 \times 60 \mathrm{~cm}$ $\left(\mathrm{F}_{5} \mathrm{D}_{3}\right)$ and $100 \% \mathrm{RDF}$ of NPK +Azotobacter + PSB culture + spacing of $60 \times 45 \mathrm{~cm}\left(\mathrm{~F}_{6} \mathrm{D}_{2}\right)$, where flower yield was $598.79 \mathrm{~g} /$ plant and $594.94 \mathrm{~g} /$ plant, respectively. While, maximum flower yield per plot (14.27 $\mathrm{kg})$ as well as per hectare (220.29 q) was recorded with $100 \%$ RDF of NPK +Azotobacter + PSB culture + spacing of $60 \times 45 \mathrm{~cm}\left(\mathrm{~F}_{6} \mathrm{D}_{2}\right)$ followed by $100 \%$ $\mathrm{RDF}$ of NPK + spacing of $60 \times 45 \mathrm{~cm}\left(\mathrm{~F}_{5} \mathrm{D}_{2}\right)$, where flower yield was $13.38 \mathrm{~kg} / \mathrm{plot}$ and $206.29 \mathrm{q} / \mathrm{ha}$, respectively. The increase in flowers yield might be due to the fact that they influenced synergetically on these parameters. This may also be due to the fact that optimum plant population per unit area and better nutrient levels brought better growth of plant which resulted in more flower yield. Although, flower yield per plant was more in $\mathrm{F}_{6} \mathrm{D}_{3}$ combination, it was not able to compensate higher yield per plot as well as per hectare because of less plant population per unit area as compared to $\mathrm{F}_{6} \mathrm{D}_{2}$ combination. The present results are also similar to the findings of Natarajan and Vijayakumar (2002) in marigold, and Ahirwar et al. (2012) in African marigold.

\section{Conclusion}

It was concluded that application of $100 \%$ RDF of $\mathrm{NPK}+$ Azotobacter + PSB along with $60 \mathrm{~cm} \mathrm{X} 45 \mathrm{~cm}$ spacing exhibited significantly maximum average weight of flower, yield of flowers per plot as well as per hectare.

\section{REFERENCES}

Acharya, M.M. and Dashora, L.K. (2004). Response of graded level of $\mathrm{N}$ and $\mathrm{P}$ on vegetative growth and flowering in African Marigold. Journal of Ornamental Horticulture, 7(2): 179-183

Ahirwar, M. K., Ahirwar, K. and Shukla, M. (2012). Effect of plant densities, nitrogen and phosphorus levels on growth, yield and quality of African marigold. Annals of Plant and Soil Research, 14 (2): 153-155

Arakeri, H. R., Chatan, G. V., Satyanarayan, P. and Donahai, R. L. (1956). Soil management in India. Ashia Publishing House, Bombay.

Baboo, R. and Singh, M. K. (2003). Response of graded level of $\mathrm{N}$ and $\mathrm{P}$ on growth and flowering in African Marigold. Journal of Ornamental Horticulture, 6 (4): 400402

Barea, J. M. and Brown, M. E. (1974). Effect on plant growth produced by Azotobacter paspali related to synthesis of plant growth regulating substances. Journal of Applied Bacteriology, 37: 583-586

Deshmane, S., Khiratkar, S. D, Panchbhai, D. M., Jibhakate, P., Pakhale, S. And Jayade B. B. (2012). Effect of planting time and spacing on quality and yield of African marigold. Journal of soils and crops, 22 (1): 172-176

Dorajeerao, A.V.D. and Mokashi, A.N. (2013). Growth analysis as influenced by planting geometry in garland chrysanthemum. Global Journal Bioscience Biotechnology, 2(1): 21-26

Khalaj, M. A. Edrisi, B. and Amiri, M. (2012). Effect of nitrogen and plant spacing on nutrients uptake, yield and growth of tuberose (Polianthestuberosa L.). Journal of Ornamental Horticulture, 5 (1): 2251-6433

Kour, R. (2009). Flowering production as effected by spacing and pinching in chrysanthemum cv. Flirt. International Journal Agriculture Sciences, 5 (2): 588-589

Lakshmi., K. Rajesh, Pandey, D., Sheetal, L. Nomita, Bhat, D., Singh, A. and Jamwal, S. (2014). Studies on effects of planting dates and spacing in African marigold (Tageteserecta L.). Progressive Horticulture, 46: 1

Luthra, K. L., Saha, S. K. and Awaski, P. K. (1983). Role of rock phosphate in present day Agriculture. Indian Journal of Agriculture Chemistry, 15: 13-27

Mittal, R., Patel, H.C., Nayee, D.D., and Sitapra H. H. (2010). Effect of integrated nutrient management on growth and yield of African marigold (Tageteserecta L.) cv. 'Local under middle Gujarat agro-climatic conditions. Asian Journal of Horticulture, 5(2):347-349

Natarajan, K. and Vijayakumar, A. (2002). Effect of fertilizer and spacing on seed yield and quality in marigold cv. African giant. Advances in Plant Sciences, 15(2):525532

Natarajan, N., Cork, A. Boomathi, N., Pandi, R.,Velavan, S. and Dhakshnamoorthy, G. (2006). Cold aqueousextracts of African marigold, Tageteserecta, for control of tomato root knot nematode, Meloidogyne incognita. Crop Protection, 25: 1210-1213

Pal, A. and Pandey, A. K. (2007). Effect of plant spacing on growth and flowering in African marigold (Tageteserecta L.) under Bundelkhand Region. Progressive Research, 2 (1/2): 70-72

Sharma, B.P., Sharma, Y.D. and Dilta, B.S. (2006). Studies of NPK nutrition on growth and flowering in chrysanthemum. International Journal of Plant Sciences, Muzaffarnagar, 1 (1): 32-35

Singh, P., Prakash, S., Kumar, M., Malik, S., Singh, M. K. and Kumar, A. (2015). Effect of integrated nutrient management (INM) on growth, flowering and yield in Marigold (Tageteserecta L.) cv. Pusa Basanti. Annals of Horticulture, 8 (1): 73-80

Stockman, Y.M., Fischer, R.A. and Brittain, E.G. (1983). 
Manoj Kumar Rolaniya et al. / J. Appl. \& Nat. Sci. 9 (1): 593 - 597 (2017)

Assimilate supply and floret development within the spike of wheat. Australian Journal of Plant Physiology, $10: 585-594$

Sunitha, H. M., Hunje, R., Vyakaranahal, B. S. and Bablad, H. B. (2007). Effect of plant spacing and INM on yield and quality of seed and vegetative growth parameters in African marigold. Journal of Ornamental Horticulture, 10: $245-249$

*Wange, S. S. and Patil, P. L. (1994). Response of tuberose to biofertilizers and nitrogen. Journal of Maharashtra Agricultural University, 19 (3): 84-85

Warden, W.W. and Windrich, W.A. (1974). Studies on nematological problem in horticulture. Agriculture Co-operation Project, Indonesia, 393-402

Yadav, R.M., Dubey, P. and Asati, B.S. (2004). Effect of spacing and nitrogen levels on growth, flowering and flower yield of marigold (Tageteserecta L.). Orissa Journal of Horticulture, 32 (1): 41-45 